\title{
Factors Affecting Treatment and Prognosis in Thymomas: A Multi-Center Experience
}

\author{
(1) Şule KARABULUT GÜL, ${ }^{1}$ (1) Hüseyin TEPETAM, ${ }^{1}$ (I) Şule KARAMAN, ${ }^{2}$ (D) Şimay GÜROCAK, ${ }^{3}$ \\ (1) Esra KORKMAZ KIRAKLI, ${ }^{4}$ (1) Ibrahim BABALIOĞLU, ${ }^{5}$ (C) Eda ERDiş, ${ }^{6}$ (1) Pelin ALTINOK ${ }^{7}$
}

\author{
'Department of Radiation Oncology, University of Health Sciences Lütfi Kırdar Kartal Training and Research Hospital, İstanbul-Turkey \\ ${ }^{2}$ Department of Radiation Oncology, İstanbul University Faculty of Medicine, İstanbul-Turkey \\ ${ }^{3}$ Department of Radiation Oncology, İnonu University Faculty of Medicine, İstanbul-Turkey \\ ${ }^{4}$ Department of Radiation Oncology, Ege University Faculty of Medicine, İstanbul-Turkey \\ ${ }^{5}$ Department of Radiation Oncology, Konya Education and Research Hospital, Konya-Turkey \\ ${ }^{6}$ Department of Radiation Oncology, Cumhuriyet University Faculty of Medicine, İstanbul-Turkey \\ ${ }^{7}$ Department of Radiation Oncology, Ümraniye Training and Research Hospital, İstanbul-Turkey
}

\begin{abstract}
OBJECTIVE
Thymomas, a rare malignancy, are located in 95\% anterior mediastinum. They are associated with paraneoplastic syndromes, especially myasthenia graves. Although many classifications are used considering the depth of invasion, presence of metastasis, predominant cell type, or immunohistochemical properties in staging, Masoaka classification is commonly used. Surgery is the most effective method in the treatment of thymoma, and neoadjuvant chemotherapy is recommended in advanced stages (III-IV). Adjuvant radiotherapy has proven efficacy in advanced and inoperable patients. In this study, we aimed to evaluate treatment outcomes and factors affecting prognosis in thymoma patients.
\end{abstract}

\section{METHODS}

Patients with thymoma who were included in this study voluntarily from seven centers between January 2002 and August 2018 were evaluated retrospectively.

\section{RESULTS}

Of the 158 patients with thymoma, 125 patients with complete data were included in this study. The mean age of the patients was 51.84 (18-84), and 72 were male. Myasthenia graves were present in 64 patients. One hundred thirteen patients were operated and 12 were inoperable. One hundred patients were stage 2, 9 were stage 3 , and 16 were stage 4 . In our study, 3 -year survival was $84.4 \%$, and 5 -year survival was $74.9 \%$; inoperable patients, surgical margin positivity, advanced disease and radiotherapy dose less than $50.4^{\prime} \mathrm{Gy}$ were found to be negative factors affecting survival. In patients with myasthenia graves (MG), survival was higher in patients with stage $2 B$ and less. Survival was lower in epithelial type $\mathrm{B} 3$ and type $\mathrm{C}$ histologic types. Age, sex, and capsule involvement did not seem to affect survival.

\section{CONCLUSION}

Thymoma is a locally controlled disease with long survival and the results of our study are consistent with the literature. The number of patients should be increased to better define prognostic factors.

Keywords: Radiotherapy; surgery; thymoma.

Copyright $\odot$ 2020, Turkish Society for Radiation Oncology

Received: January 16, 2020

Accepted: January 25, 2020

Online: January 30, 2020

Accessible online at:

www.onkder.org

OPEN ACCESS This work is licensed under a Creative Commons

Attribution-NonCommercial 4.0 International License.
Dr. Şule KARABULUT GÜL

Sağlık Bilimleri Üniversitesi,

Dr. Lütfi Kırdar Kartal Eğitim ve Araştırma Hastanesi,

Radyasyon Onkolojisi,

İstanbul-Turkey

E-mail: sulegul2003@yahoo.com 


\section{Introduction}

Thymomas are rare tumors that may occur at any age, 95\% of which are located in the anterior mediastinum and are often accompanied by paraneoplastic syndromes. They are most commonly associated with Myasthenia Graves. The staging of thymoma has been made differently according to tumor invasion, presence of metastasis, cell type and immunohistochemical properties. The first staging was performed in 1976, and in 1999, a histopathological classification was accepted by WHO (Table 1). Masaoka classification is widely used today (Table 2) and includes tumor invasion, clinical and histopathological features. Patients with thymoma are clinically asymptomatic and 30\% have signs of MG. Complete surgical resection is the most effective method in the treatment of thymomas. Complete surgical resection is performed in Masaoka stage I-II and selected patients.

Chemotherapy is an effective treatment modality in inoperable patients, and many retrospective studies have shown that postoperative radiotherapy in invasive thymomas is effective for local control and survival. Stage I thymoma does not require additional treatment after surgery. In stage II thymoma, adjuvant radiotherapy is necessary to reduce the risk of recurrence, especially in the histological group B2, B3 and C. The efficacy of regimens with cisplatin and radiotherapy in stage III and IV thymomas has been demonstrated by studies. The recommended dose for RT is $45-55 \mathrm{~Gy}$.

\section{Materials and Methods}

Between January 2002 and August 2018, 125 patients admitted with thymoma were evaluated retrospectively in this study. The data to be examined were shared with the centers wishing to participate. SPSS statistical program was used for evaluation. Survival was evaluated by the Kaplan Meier method, and comparisons between survival curves were evaluated by the Long-Rank test. A p-value of 0.05 or less was considered statistically significant and factors affecting treatment and prognosis

\begin{tabular}{|c|c|}
\hline Table 1 & 1999 WHO histopathological classification \\
\hline Type A & Spindle cells \\
\hline Type AB & Mixed spindle cells and lymphocytes \\
\hline Type B1 & Lymphocytes>epithelial cells \\
\hline Type B2 & Mixed lymphocytes and epithelial cells \\
\hline Type B3 & Predominant of epithelial cells \\
\hline Type C & Thymic carcinoma \\
\hline
\end{tabular}

\section{Table 2 Masaoka staging}

\begin{tabular}{lc} 
I & Encapsulated tumor \\
II & Microscopic capsular invasion (Ila) or \\
III & Macroscopic invasion into fatty tissue (IIb) \\
IVA & Invasion into great vessels, pericardium, or lung \\
IVB & Pleural and/or pericardial dissemination \\
\hline
\end{tabular}

Table 3 Patient numbers according to WHO

\begin{tabular}{lcc} 
Evre & $\mathbf{n}$ (number of patients) & \% (percent) \\
\hline Type A & 5 & 4 \\
Type AB & 16 & 12.8 \\
Type B1 & 22 & 17.6 \\
Type B2 & 47 & 37.6 \\
Type B3 & 33 & 26.4 \\
Type C & 2 & 1.6 \\
\hline
\end{tabular}

were reviewed in the light of literature. A total of 158 patient data were reviewed, and 125 patients with complete data were included in this study. The mean age was $51.18(18-84)$ and 72 (57.6\%) were males. One hundred thirteen patients were operated (90.4\%), and $33(26.4 \%)$ had positive surgical margins. Capsule invasion was positive in 85 patients $(68 \%)$ and mediastinal fatty tissue invasion was found in 86 patients $(68.8 \%)$. Fifteen patients (12\%) had lymph node positivity.

According to Masoaka classification, 100 patients (80\%) had stage III, nine patients (7.2\%) had stage III, 16 patients $(12.8 \%)$ had stage IV. The stages by WHO are shown in Table 3.64 patients $(51.2 \%)$ had also MG.

\section{Results}

In our study, the follow-up period was 47 months (1189 ), and 3 -year survival was $84.4 \%$ and 5 -year survival was $74.9 \%$ (Fig. 1). When we look at the survival according to Masaoka Staging, 3-year survival was $88.7 \%$, 5 -year survival is $84.1 \%$, and 3 -year survival was $69.3 \%$, and 5 -year survival was $31.2 \%$ (Fig. 2). Progressionfree survival was $81.4 \%$ for three years and $73.6 \%$ for five years. Survival by age was evaluated under 60 years of age and above, and no statistical significance was found in survival $(\mathrm{p}=0.261)$. The mean survival was 133 months in women, 122 months in men, and the difference was not significant (0.122). Survival was better in operated patients than in non-operated patients $(p=0.002)$, and surgical margin negativity was significantly better than surgical margin positivity $(\mathrm{p}=0.019)$. 


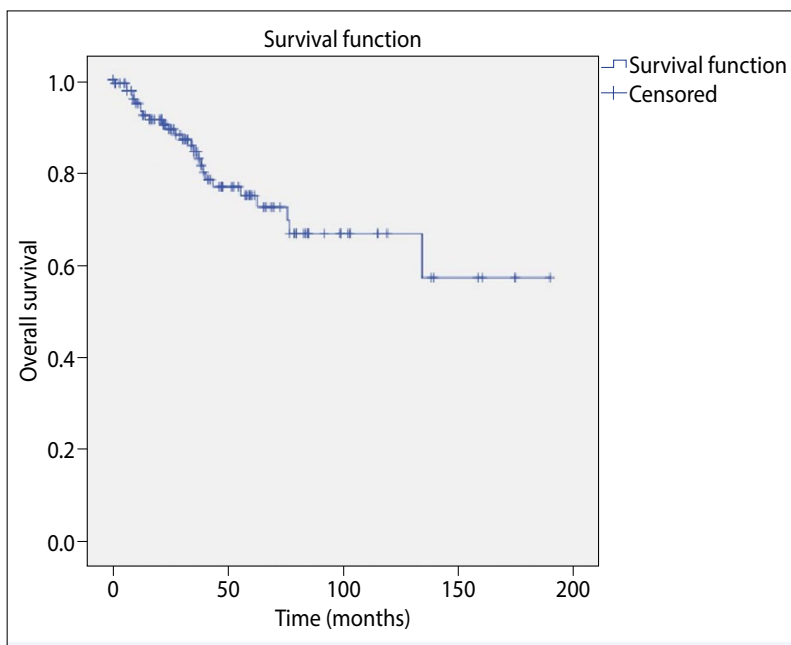

Fig. 1. Survival.

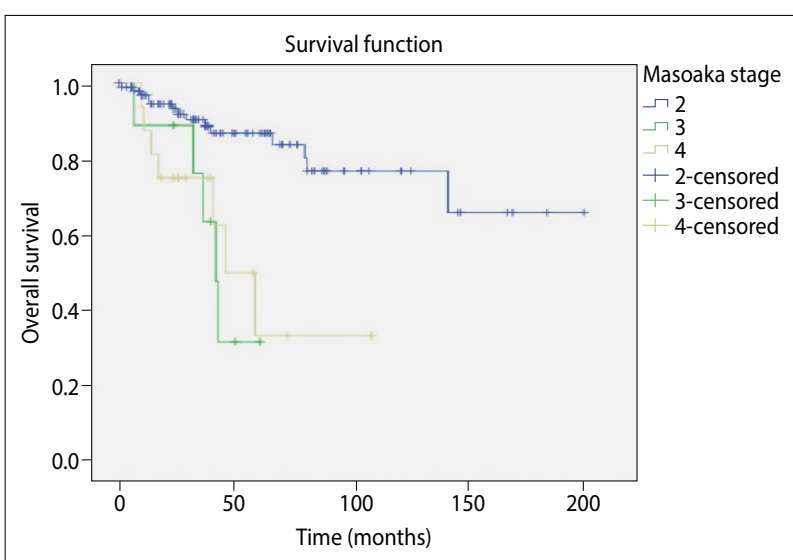

Fig. 2. Survival according to Masaoka staging.

The presence of capsule involvement is not effective for survival. No significant difference concerning the stage on survival was found between Type $\mathrm{A}-\mathrm{AB}$ and $\mathrm{B} 1$ $B 2(p=0.88)$, while a statistically significant difference was found between Type $\mathrm{A}-\mathrm{AB}$ and $\mathrm{B} 3-\mathrm{C}(\mathrm{p}=0.017)$ and between type $\mathrm{B} 1-\mathrm{B} 2$ and $\mathrm{B} 3-\mathrm{C}(\mathrm{p}=0.0009)$. According to Masoaka staging, there was a significant difference in survival between stage 2 and stage $3(p=0.001)$ and stage 2 and stage $4(\mathrm{p}=0.001)$, while no significant difference was observed between stage 3 and stage $4(\mathrm{p}=0.734)$. Significance in survival difference between stage 1-2 and stage $3-4$ was found to be increased ( $\mathrm{p}=0.000)$. One hundred sixteen patients received radiotherapy, 59 patients received $50.4 \mathrm{~Gy}$ or less and 57 patients received $50.4 \mathrm{~Gy}$ or more doses. The survival rate was found to be better in the group receiving a radiotherapy dose of $50.4 \mathrm{~Gy}$ or less $(\mathrm{p}=0.02)$. The mean survival in 15 patients with lymph node positivity was 50.6 months, and in lymph node-negative patients, the survival was 141.8 months $(\mathrm{p}=0.002)$, which were statistically significant. The survival rate of patients with myasthenia graves was 163.7 months, and survival was better than the group without myasthenia and was statistically significant.

\section{Discussion}

Although thymomas have benign cytological structures, they can be invasive tumors.[1,2] It is difficult to determine prognostic factors due to their rarity. The association of thymomas with Myasthenia Graves is between $15-60 \%$ in studies.[3-5] In our study, the association of MG with thymoma was found to be $51.2 \%$. The cause of death in thymoma patients is mostly due to MG and local progression of tumor in patients without MG.[6] In many studies, there was no difference in the prognosis in patients with MG and in patients without MG, but in some studies, better prognosis was found in patients with MG.[2,6,7] As seen in the studies, the reason for the better survival in the group with MG is thought to be due to the early diagnosis of these patients in the early stages. In our study, it was observed that patients with $\mathrm{MG}$ had stage $2 \mathrm{~B}$ and below and had longer survival $(\mathrm{p}=0.045)$.

In the studies, R0 surgery, WHO staging and Masaoka staging have been shown as the most important factors determining survival.[8-11] Subtotal resection compared to biopsy alone, showed that subtotal resection improves prognosis in some studies, and no significant result was found in others. In our study, survival was significantly better in the surgical group $(\mathrm{p}=0.002)$.

There is no clarity in studies evaluating cell types. $[6,12,13]$ While some of them suggest that cell type is important, there are studies showing that cell type has prognostic value because epithelial and mixed types are more invasive. In our study, the overall survival rate was found to be statistically lower in both types B3 and $\mathrm{C}$ compared to other types. In addition, in accordance with the literature, the survival rate decreased according to Masoaka staging and was statistically significant.

If complete resection of stage I is performed in thymoma, no additional treatment is required. As the risk of recurrence increases in stages 2-3, adjuvant RT is given.

In the literature, RT results are available in different doses and fractions, and the recommended dose is 45-55Gy. In our study, RT was administered to patients starting from stage 2 , and the doses used were between 45-54 Gy. When the RT dose was evaluated, overall survival was found to be statistically lower in the group that received the dose above $50.4 \mathrm{~Gy}$. In patients given a 
high dose of RT, it was thought that the high stage was effective in this result.[11,14-17]

Secondary malignancies have been reported in thymomas. Especially nonhodgkin lymphoma and soft tissue sarcomas were determined. Secondary malignancy was not found in our study.

Overall 10-year survival rate was reported to be $80 \%$ in stage I, and overall survival seem to decrease as the stage increase. In our study, a decrease in overall survival was observed in patients with stage 3 and above in accordance with the literature.

Our study includes data of seven centers. Our results are consistent with the literature and being operable, the negativity of surgical margins, early-stage disease, the coexistence of MG was found to be positive factors affecting overall survival.

\section{Conclusion}

In conclusion, thymoma is still a controversial issue in the literature with its rarity. The number of patients should be increased to better define the prognostic factors in thymoma patients as they generally have long survival.

Peer-review: Externally peer-reviewed.

Conflict of Interest: We state that there is no conflict of interest regarding the publication of this paper.

Ethics Committee Approval: An ethic approval was taken from: "University of Health Sciences, Dr.Lütfi Kirdar Kartal Training and Research Hospital Ethics Committee, İstanbulTurkey" in 06.12.2019 with a number of 2019/514/167/15.

Financial Support: None declared.

Authorship contributions: Concept - Ş.K.G., H.T.; Design - P.A., Ş.K.; Supervision - İ.B., E.E.; Funding - None; Materials - E.K.K., E.E.; Data collection and/or processing - Ş.K.G., H.T.,S.K., Ş.G., E.K.K., İ.B., E.E., P.A.; Data analysis and/or interpretation - H.T., İ.B.; Literature search - Ş.G., P.A.; Writing - Ş.K.G., Ş.G.; Critical review - Ş.K., Ş.K.G.

\section{References}

1. Lewis JE, Wick MR, Scheithauer BW, Bernatz PE, Taylor WF. A clinicopathologic review. Cancer 1987;60(11):2727-43.

2. Masaoka A, Monden Y, Nakahara K, Tanioka T. Follow-up study of thymomas with special reference to their clinical stages. Cancer 1981;48(11):2485-92.

3. Scorsetti M, Leo F, Trama A, D’Angelillo R, Serpico D, Macerelli M, et al. Thymoma and thymic carcinomas. Crit Rev Oncol Hematol 2016;99:332-50.
4. Sperling B, Marschall J, Kennedy R, Pahwa P, Chibbar $\mathrm{R}$. Thymoma: A review of the clinical and pathological findings in 65 cases. Can J Surg 2003;46(1):37-42.

5. Girard N, Ruffini E, Marx A, Faivre-Finn C, Peters S; ESMO Guidelines Committee. Thymic epithelial tumours: ESMO Clinical practice guidelines for diagnosis, treatment and follow-up. Ann Oncol 2015;26 (Suppl 5):v40-55.

6. Maggi G, Casadio C, Cavallo A, Cianci R, Molinatti M, Ruffini E. Results of 241 operated cases. Ann Thorac Surg 1991;51:152-6.

7. Wilkins EW Jr, Grillo HC, Scannell JG, Moncure AC, Mathisen DJ. Role of staging in prognosis and management of thymoma. Ann Thorac Surg 1991;51(6):888-92.

8. Regnard JF, Magdeleinat P, Dromer C, Dulmet E, de Montpreville V, Levi JF, et al. Prognostic factors and long-term results after thymoma resection: A series of 307 patients. J Thorac Cardiovasc Surg. 1996 Aug;112(2):376-84.

9. Fuentes P, Leude E, Ruiz C, Bordigoni L, Thomas P, Giudicelli R, et al. Treatment of thymoma: A report of 67 cases. Eur J Cardiothorac Surg 1992;6(4):180-7.

10. Demirci S, Turhan K, Ozsan N, Yalman D, Cakan A, Cok G, et al. Prognostic factors for survival in patients with thymic epithelial tumors. Thorac Cardiovasc Surg 2011;59(3):153-7.

11. Zhu G, He S, Fu X, Jiang G, Liu T. Radiotherapy and prognostic factors for thymoma: A retrospective study of 175 patients. Int J Radiat Oncol Biol Phys 2004;60(4):1113-9.

12. Cohen DJ, Ronnigen LD, Graeber GM, Deshong JL, Jaffin J, Burge JR, et al. Management of patients with malignant thymoma. J Thorac Cardiovasc Surg 1984;87(2):301-7.

13. Marulli G, Margaritora S, Lucchi M, Cardillo G, Granone $\mathrm{P}$, Mussi A, et al. Surgical treatment of recurrent thymoma: is it worthwhile? $\uparrow$. Eur J Cardiothorac Surg 2016;49(1):327-32.

14. Nakahara K, Ohno K, Hashimoto J, Maeda H, Miyoshi S, Sakurai M, et al. Thymoma: result with complete resection and adjuvant postoperative irradiation in 141 consecutive patients. J Thorac Cardiovasc Surg 1988;95(6):1041-7.

15. McCart JA, Gaspar L, Inculet R, Casson AG. Predictors of survival following surgical resection of thymoma. J Surg Oncol 1993;54(4):233-8.

16. Arakawa A, Yasunaga T, Saitoh Y, Uozumi H, Takada C, Baba Y, et al. Radiation therapy of invasive thymoma. Int J Radiat Oncol Biol Phys 1990;18(3):529-34.

17. Shin DM, Walsh GL, Komaki R, Putnam JB, Nesbitt J, Ro JY, et al. A multidisciplinary approach to therapy for unresectable malignant thymoma. Ann Intern Med 1998;129(2):100-4. 